
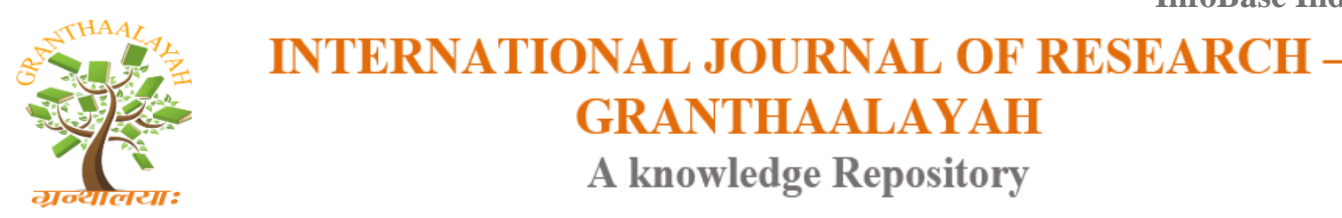

Management

\title{
DUAL CAREER COUPLES IN KOLKATA AND THEIR STRESSFUL WORK LIFE BALANCE
}

\author{
Jhilam Rudra De $\mathrm{e}^{* 1}$ \\ ${ }^{* 1}$ Assistant Professor, NSHM College of Management and Technology, Kolkata, India
}

DOI: https://doi.org/10.29121/granthaalayah.v5.i3.2017.1771

\begin{abstract}
Dual-career couples were exceptions to the norm in the 1960s, but on date it is difficult to assess the number of married career women in the work force. Previous researches suggest that, the problems of the working women, who are a significant part of a dual career couple, may include lack of flexibility in the workplace, male-trailing spouses, career versus relationship child bearing conflicts etc. The key for dual career couples is to establish a system to help them balance their career and personal activities. For each couple the dynamics are little different, depending on their personal situations. The main aim of this research is to study the level of stress to maintain work life balance of the dual career couples, where the female counterparts are working in the private health sector in Kolkata. Cronbach alpha was used as a reliability test. Independent sample t-tests were used to study the effect of gender and family structure on respondents' satisfaction towards WLB. Nowadays, a career is not a mere need, but rather, a necessity. It is evident that an understanding, accommodating, and sympathetic approach to the management of dual career stress can improve organizational effectiveness by fostering continued employment and maximum performance among dual career couples.
\end{abstract}

Keywords: Dual Career; WLB; Performance; Flexibility; Satisfaction.

Cite This Article: Jhilam Rudra De. (2017). "DUAL CAREER COUPLES IN KOLKATA AND THEIR STRESSFUL WORK LIFE BALANCE." International Journal of Research - Granthaalayah, 5(3), 213-222. https://doi.org/10.29121/granthaalayah.v5.i3.2017.1771.

\section{Introduction}

A significant influence on contemporary Indian living status is based on the increasing rate of female participation in the labor force. Evidences from the early $20^{\text {th }}$ century saw the division between the economic and domestic activities, which marked a major division between the sexes. When economic activity was distinguished from the household activities, it was women who were consigned to the domestic sphere while men moved in to the sphere of employment. Gradually situation changed. Statistics reveals that the married woman is the key source of this growth. As more and more women are educated and trained, they are on their ways to add some 
value in their professional literature. Much of the literature implies that a significant feature of the dual-career life-style is that it produces considerable stress and strain. Study of the dualcareer family is a relatively new research area, having its genesis in the late 1960s. Rapoport and Rapoport (1969) originated the term "dual- career family." Dual-career couples are those where both the husband and wife of the family pursue careers that require a high degree of commitment, special training, with a continuous developmental nature adding to increasing degrees of responsibility. Such families were exceptions to the norm in the 1960s, but have steadily increased in prevalence in the 1970s and early 1980s. And on date it is difficult to assess the number of married career women in the work force, it seems reasonable to assume that the percentage for this group is positively related to the general increase in labor force participation rates of women (Hopkins \& White, 1978). Changing role of women, however, created some constraints to the existing lifestyle, which might be explained by the fact that it is a relatively new and minority pattern. From a societal point of view, dual career couples in India especially those with young children, frequently feel overwhelmed by their lifestyle. The external demands of the workplace, children's needs, and household responsibilities compete for limited time, creating obvious stress on the dual career couple. Guilt, anxiety, alienation, powerlessness, rigidity, anger and competition are common obstacles to success and satisfaction for dual career couples. In coping with the pressures of this variant pattern, dual-career couples have been forced to come up with their own individual solutions as no institutionalized supports exist (Holmstrom 1973). The research on dual-career families has been primarily descriptive in nature and has focused on women. Previous researches suggest that, the problems of the working women, who are a significant part of a dual career couple, may include lack of flexibility in the workplace, lack of family-friendly workplace policies, parent-track policies, male-trailing spouses, career versus relationship and child bearing conflicts. Absence of female role models and inadequate number of female members at the top ranks add to the disadvantages.

\section{Objective}

Despite of economic advantages, dual career couples have a different set of challenges than couples that are single-income. The key for dual career couples is to establish a system to help them balance their career and personal activities. For each couple the dynamics are little different, depending on their personal situations, for example - level of education, job location, career aspirations, age, number of kids, existence of aged and dependent relatives and hobbies. The objectives of this paper are:

- To find reasons of stress among the dual career couples.

- To identify the level of balance between work and family life among dual career couples.

\section{Literature Review}

Rapoport and Rapoport, who coined the term "dual-career family" in 1969, were pioneers in the study of the impact of career and family on each other. Their research was followed shortly thereafter by other definitive studies on the dual-career lifestyle by other researchers like Epstein, 1971; Holmstrom,1973; Garland,1972; Poloma,1972 etc. The purpose of this literature review is to determine the sources of dual-career strain and stress. 
Indian families are undergoing changes. The family environments have been broadly influenced with new expectations, the standard of living set by media, high cost of living and a striving for better quality of life. The dual-earning couple is a new prototype that reflects the increasing educational and career aspirations of women. Women globally belonging to any class or creed have progressed and reached a new paradigm. They have established their freedom, selfautonomy and personal growth, are better able to express themselves, and are striving hard to achieve their objectives. These new roles are the additional to traditional roles and responsibilities of bearing and rearing children and management of domestic and household. A significant proportion of these women in the workforce comprises of wives and mothers whose employment status demands a radical change in their pattern, activities, commitments and responsibilities, requiring a reassessment of the family environment. In India the work participation rate for women has increased in the recent decades. On the flipside, women have to balance identity, power and status with family roles and responsibilities often in conflict and psychological distancing from the spouse resulting in tension, stress and strain. There is a clash between the domestic roles and the job roles for working couples. Sources of stress in the lives of working women emerged from a lack of time to attend to multiple roles, presence of young children (0-12 years) in the family and additional responsibility at work in the form of promotions. The most common outcome of stress for the working woman was found to be poor mental and physical health resulting in depression, burnout, anxiety, headache, asthma and colitis.

Healthcare is a high-demand, high-stress, high-risk industry. It operates in a round the clock manner, for the whole year and mostly healthcare workers are involved in matters of life and death. Healthcare workers have to continuously work with other people at the emotional level. The working environment of the private hospitals plays a major role in increasing the mental fatigue of health care workers. Some of the factors responsible for high pressure are: patient satisfaction scores, competitive performance edge, performance and productivity targets etc. All these things have a great impact on the emotional wellbeing and stress level of workers, working in the health care sector.

A balanced life and fulfilling life is what everyone strives to get but it becomes very difficult for the dual-career couples as they are unable to identify themselves in perfect alignment with both work and home spheres. Achievements, status quo and recognition have become a necessity for the modern couple while they equally strive hard to be the perfect spouses/super moms and super dads at home too. Hassan (2010) explained that people in eastern countries, have different practices on work and family when compared with western countries. It is found to be due to differences in cultural traditions, family structures and societal institutions. In a culture-rich country like India, the value system has a strong impact on family sphere and hence demands lots of attention and time to it. Dual-career couples are more prone to these pressures of balancing work-life as they have the dual responsibilities of managing both work and home with conflicting demands, pressures and situations every day in their regular lives. Buddhapriya (2009) found that Indian employees face higher family-oriented responsibilities and hence, workfamily conflict has a serious bearing on the psychological well-being of Indian working professionals. Perlow (1998) observed that the rise in women workforce has increased not only the number of dual-career couples, but also their entry into professional and managerial ranks and has therefore forced them to confront the long working hours. The demands on their time are 
therefore exceedingly high. Rout et al. (1999) observed that women in India experience considerable pressure at home to do all that is necessary for the family before going out to work and after work. Because of the demands of work, Indian women are unable to perform the traditional roles at home as expected. A working women's life sounds more complex as Indian societal values deter men from actively participating in the household activities. Some men share the responsibilities at home and also suffer from the burden of trying to meet the demands of both work and family. Research by Mathew and Panchanatham (2011) the prominent WLB issues that the working women face are role overload, health maintenance problems, poor time management, dependent care issues and lack of sufficient support networks.

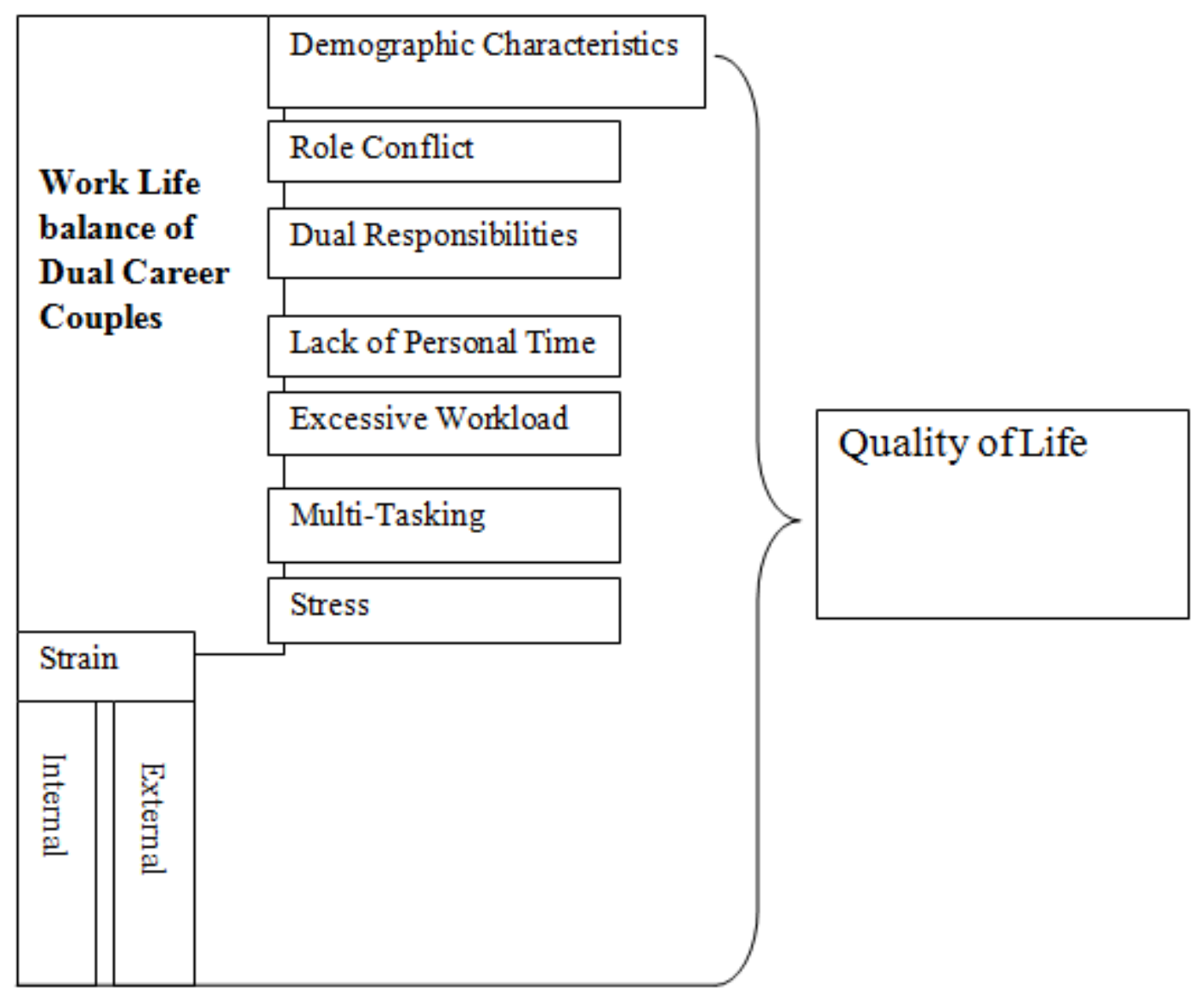

Figure 1: Work Life Balance of Dual Career Couples- Conceptual Framework

Qualities of life of the dual career couple are somehow dependent on various factors like-

\section{Dual responsibilities}

Dual responsibilities at both home and workplace can be taxing for both the members of dualcareer couple resulting into work-family spillover and conflict. Most of the time, there is an inability to fulfill the expectations of both work and family leading to uneasiness between themselves. According to Kossek et al. (2012), the tendency of being constantly available to work for a long tenure of time and not engaging in home life is prevalent due to insecurity about one's job. Work to family spillover creates problems in having a happy family. 


\section{Lack of Personal Time}

Dual-career couples are the ones who are most likely to experience the issue of lack of personal time compared to others as they have more work to do in a little time, especially at home as a result of their high combined working hours (White et al. 2003). Managing time is one of the biggest issues and multitasking is the only solution to cope up effectively. According to Rubinstein et al. (2001), multitasking is too much stressful, tiring and believed to reduce productivity. Lack of time for ownself leads to frustrations in personal life as there is no time to relax, engage in leisure activities or maintain social relationships and strengthens the family bonding.

\section{Role conflict}

Ashforth et al. (2000) found that work-family imbalance for a dual career couple is a consequence of highly integrated work and family roles. There is always a risk of conflict between the two roles of profession and family spheres among the dual-career couples. Individuals in dual-career situations have to balance the two roles simultaneously, and often are exposed to conflicting, demands and pressures of two careers with those of the family.

\section{Excessive Workload}

Clarkberg and Moen (2001) state that over working for long tenure is highly prevalent among dual-career working professionals. Work load is mostly high due to job demands and the pressure to complete a given task. Despite of many responsibilities at home and role conflicts very often, dual-career couples take up the act of working late at weekends or taking work home at evenings. Overworking and excessive long working hours definitely affects the WLB of dualcareer couples especially Indians.

\section{Stress and Strain}

Research by Elloy (2001) indicates that stress is caused in dual-career couples as a result of excessive workload and family conflict. When an individual has to perform multiple roles (i.e., worker, spouse, and in some cases parent), each of these roles requires time, energy and commitment. The cumulative demands of these multiple roles appear to lead to increased levels of stress and strain. Research findings by Gupta and Tyagi (2009) suggest that managers consider WLB to be one of the most important sources of work stress. Sources of conflict and stress, however, differed along traditional lines. For instance, women experienced more conflict between their job and home roles, while men experienced more conflict between their job and spousal roles. Further, stress and strain that the dual-career couples face affects their health and well-being as well. Health-related problems like hypertension is a common say among the knowledge professionals belonging to dual-career families. Although there is a considerable degree of variation in dual-career stress, there are also common patterns. Although interactive and cyclical in nature, strains have been classified as primarily (a) internal: arising within the family; or (b) external: the result of conflict of the dual-career family and other societal structure.

\section{Research Methodology}

The main aim of this research is to study the level of stress to maintain work life balance of the dual career couples, where the female counterparts are working in the private health sector in Kolkata. The data constitute both primary and secondary data. The primary data used in the 
study was collected through structured interview and questionnaire. The study was conducted by using two separate structured questionnaires for the husband and for the wife. Some questions were identical in the both questionnaires and some were different. The questionnaires were distributed among 160 people or 80 couples, where the female counter parts work in the private health sectors located in Kolkata. The husbands in the sample were between 27-54 years of age, working in different sectors like ITES, banking sector, hospitals, multinational companies etc and the wives were between 22-50 years of age, with at least one child, working in different clinical and non-clinical designations in the health care institutes across Kolkata.

Three Stress levels were categorised as score below 50 points as 'Low' Level of Stress, between 50-100 points as 'Moderate', between101-150 points as 'High' Level of Stress. Attributes to manifestation of stress were identified as Depression, Tension, Anger, Insomnia, Absenteeism, Anxiety, Frustration, Loss of Focus, Conflicts, Physical Illness, smoking and alcoholism.

This paper explores issues pertaining to role conflicts between the dual-couples related to childcare, aged care, domestic work, role conflict, main reasons for stress, and their opinions about stress that was caused due to workload and whether they get time to finish tasks assigned at office on time. This study also discusses questions related to conflict with colleagues, working hours, time spent with family after working hours, family responsibilities, factors responsible for higher level of strain, both internal and external, and how the working couples manage strain and stressful situations, their conflicts between multiple roles.

Secondary data are collected through internet and data available from previous publications different leading journals.

The collected data were subjected to Cronbach's alpha reliability test. It was found that the scale used for measuring WLB of dual-career couples had a good Cronbach's alpha value of 0.839 which indicates a high level of internal consistency for the scale with the specific sample used for the study.

Independent sample t-tests were used to study the effect of gender and family structure on respondents' satisfaction towards WLB.

\section{Results and Discussions}

A career is not a mere need, but rather, a necessity in this modern era that both male and female players are forced to work to have a decent standard of living and single earner idea does not seem to be a wise choice. This fact makes 'WLB' an interesting research topic to ponder upon. The main focus of this study is on the WLB challenges faced by dual-career couples

Out of 160 samples, 74 individuals were found facing stress. Out of 74 respondents facing stress, $30 \%$ were found in higher stress, $34.5 \%$ in moderate level of stress and $35.5 \%$ in lower level stress (Table -1) 
Table 1: Level of Stress Faced by Dual Career Couples

\begin{tabular}{|c|c|c|c|c|}
\hline Gender & LEVEL & STRESS & & Total \\
\hline & Low $(35.5 \%)$ & Moderate (34.5\%) & High $(30 \%)$ & \\
\hline Male & 15 & 13 & 9 & $37(100 \%)$ \\
\hline Female & 11 & 13 & 13 & $37(100 \%)$ \\
\hline Total & & & & $74(100 \%)$ \\
\hline
\end{tabular}

The main reasons for stress and role conflict regarding work life imbalance of dual career couple are found to be excessive work pressure, long working hours, strict words from boss, misunderstanding with seniors and peer group members, preparing homework for the children and making them ready for school, domestic chores like cooking, cleaning etc. The reasons also include leave related issues, unpleasant words from boss, financial crisis and inability to cope up with the situation, conflict with spouse etc.

Table 2: Manifestation of High Level of Stress

\begin{tabular}{|l|l|l|}
\hline \multicolumn{1}{|c|}{ Attributes } & \multicolumn{2}{c|}{ Gender } \\
\hline & Men & Women \\
\hline Depression & $5(9)$ & $12(13)$ \\
\hline Tension & $9(9)$ & $10(13)$ \\
\hline Anger & $7(9)$ & $9(13)$ \\
\hline Insomnia & $3(9)$ & $13(13)$ \\
\hline Absenteeism & $4(9)$ & $10(13)$ \\
\hline Lossof Focus & $5(9)$ & $12(13)$ \\
\hline Anxiety & $5(9)$ & $13(13)$ \\
\hline Frustration & $4(9)$ & $13(13)$ \\
\hline Conflict & $6(9)$ & $11(13)$ \\
\hline Physical Illness & $4(9)$ & $12(13)$ \\
\hline Smoking and alcoholism & $7(9)$ & $8(13)$ \\
\hline
\end{tabular}

WLB has become more like a dilemma for dual-career couples as they are much more vulnerable than single-earners in the act of juggling between their life at work and home. In the Indian context, WLB brings about a lot of problems for the dual careers at both individual and familial levels. The prime reason being, the family setup in Indian homes where the children are more dependent on their parents than children of other countries in the world. Every couple also have the responsibility to take care of elderly relatives be it their parents or in-laws. There are instances wherein extended family members like parents, in-laws help dual-career families and that again corners dual-career couples to pay back their helps in the near future. This makes the roles and pressures at home more complex and has spillover effects on the jobs of dual-career couples. In the broader spectrum, the challenges of dual-career couples in terms of WLB are more complex in nature.

Table 3: Effect of Gender on Satisfaction Level towards WLB Using Independent Sample T-Test 
Independent samples t-test has been used to estimate the difference in satisfaction levels of WLB with respect to gender. The results obtained from the independent sample t-test performed are listed in Table 3(b). Table 3(a) presents the group statistics for respondents based on their gender.

Table 3(a): Group statistics of the gender of respondents

\begin{tabular}{|c|c|c|c|c|c|}
\hline \multirow{3}{*}{$\begin{array}{l}\text { I am satisfied } \\
\text { with my work } \\
\text { life balance }\end{array}$} & Gender & $\mathbf{N}$ & Mean & Std. deviation & Std. error \\
\hline & \multirow{2}{*}{$\begin{array}{l}\text { Male } \\
\text { Female }\end{array}$} & 160 & 3.98 & 1.135 & 0.111 \\
\hline & & 160 & 4.33 & 0.997 & 0.097 \\
\hline
\end{tabular}

The result of t-test for satisfaction levels of WLB and gender indicates that the responses of two groups, namely male and female are significantly different $(\mathrm{p}=0.018<0.05)$.Further, the average value of female respondents on their levels of satisfaction towards WLB is 4.33 and the corresponding average value of male respondents is 3.98, respectively. This shows that the responses from female respondents is much closer to the least degree of agreement $(4=$ disagree) to the statement 'I am satisfied with my work life balance than their male counterparts.

Based on the results in Table 3(b), it is inferred that married women are less satisfied with their WLB than married men. That is, the male members of the dual-career families are more satisfied with their WLB than their female counterparts.

Table 3(b): Independent samples t-test to compare means between the gender of respondents (male and female) on their satisfaction towards work-life balance

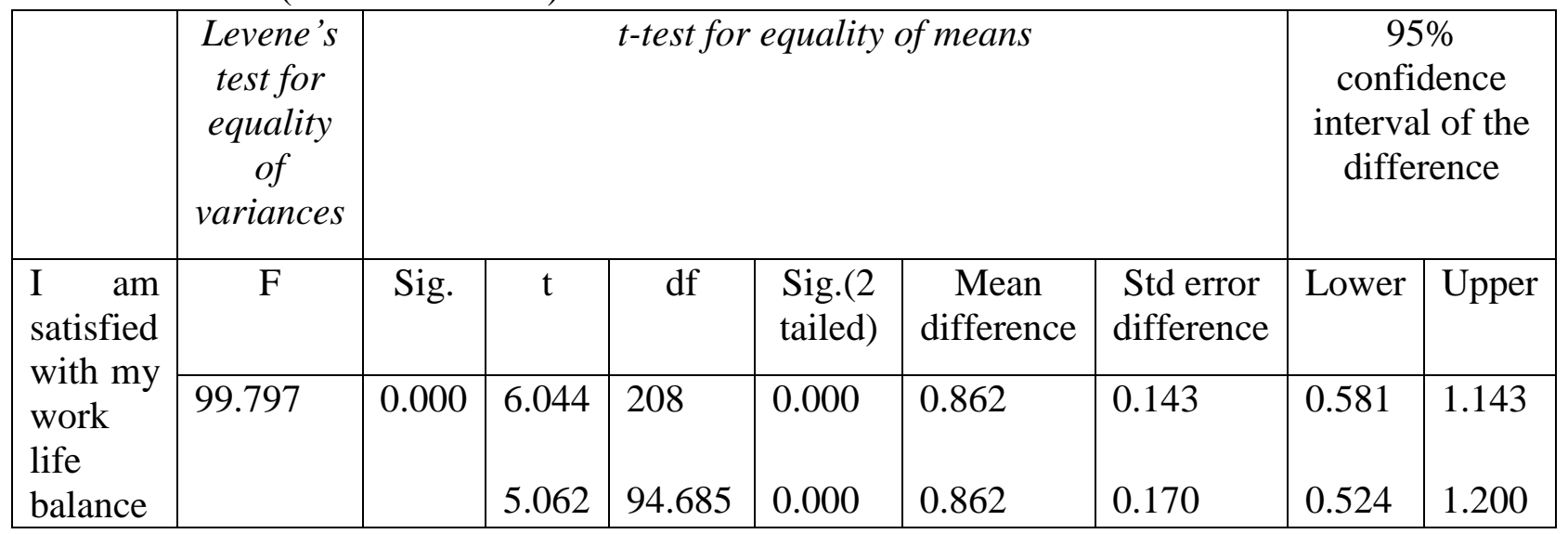

\section{Conclusion}

A career is not a mere need, but rather, a necessity in this modern era that both male and female players are forced to work to have a decent standard of living and single earner idea does not seem to be a wise choice. Long work hours, having to work at home in the evenings, worries on the effect of work stress on health, desperation to reduce work hours, lack of quality time to spend with family and work pressure affecting personal relationships are found to strongly predict the respondents' level of satisfaction towards WLB. Madipelli et al. (2013) in their study of factors influencing work-life imbalance among Indian working women observed that long working hours, pressurized work environment, etc., triggers stress and frustration among 
employees which in turn, causes WLB problems. Dual-career couples in India are helplessly caught in the act of juggling between professional and personal lives as they cannot afford to compromise on one for the sake of the other. Inability to manage time, improper delegation of work and home priorities, succumbing to the pressures of long work hours, physical and mental ill-health due to stressors make dual-career couples to be caught up in the dilemma of WLB.

On the family side, the problems of dual-career couples are very challenging. Couples have parental obligations continuing even until late adulthood years of their children and that could possibly make the dilemmas with WLB more difficult for them. Indian couples normally, do not get time for themselves as they are actively engaged in the life of their children for a very long time. Relationship with each other can also take a beating at times, because of this. With healthy elders in the form of parents or in-laws, life can be a little easy as they can manage few household chores and child rearing responsibilities, though, that again makes the couple to be obligatory towards the caretakers in the long run. But, caring responsibilities either directly or indirectly towards sick or very old relatives and dependents can cause additional pressure and work-life problems.

In some aspects women are needed to be well concentrated to improve their status. The study has implications for prevention and reduction of stress for dual career couples. The responsibility for stress reduction lies with organizations/institutions, with dual career couples and with their family members (in the Indian context). Today Indian organizations need to understand and focus on providing support to the couples for work-personal life balance. As Bruke (2002) has found that if employees perceive organizations values supportive of work-personal life balance, they experience greater job and career satisfaction, less stress and have less intention to quit and more positive emotional well-being. In order to maintain high performance of the employees, organizations may organize professional counseling programs to help the couples cope with work role stress, family role stress and work family conflict. The human resource policies should be designed, keeping in mind the stress that an employee faces at work and due to work-family conflict. Organizations could conduct training programmes, especially for women employees, to enable them to cope with their traditional roles. Stress prevention techniques like yoga, meditation, and physical exercise could also form a part of such programs' curriculum. More emphasis needs to be placed on providing counseling before the problem becomes acute rather than after dysfunctional consequences are evident.

In conclusion, it is evident that an understanding, accommodating, and sympathetic approach to the management of dual career stress can improve organizational effectiveness by fostering continued employment and maximum performance among dual career couples.

\section{References}

[1] Adams, G.A., King, L.A. and King, D.W. (1996) 'Relationship of job and family involvement, family social support, and work family conflict with job and life satisfaction', Journal of Applied Psychology, Vol. 81, No. 4, pp.411-420.

[2] Anderson, S.E., Coffey, B.S. and Byerly, R.T. (2002) 'Formal organizational initiatives and informal workplace practices: links to work-family conflict and job-related outcomes', Journal of Management, Vol. 28, No. 6, pp.787-810. 
[3] Buddhapriya, S. (2009) 'Work-family challenges and their impact on career decisions: a study of Indian women professionals', Vikalpa: The Journal for Decision Makers, Vol. 34, No. 1,pp.3145.

[4] Desai, N. and Krishnaraj, M. (1990). Women and society in India, Ajanta Publications, New Delhi.education,PP. 201-210.

[5] Fatima, N. and Sahibzada, S.A. (2012) 'An empirical analysis of factors affecting work life balance among university teachers: the case of Pakistan', Journal of International Academic Research, Vol. 12, No. 1, pp.16-29.

[6] Felstead, A., Jewson, N., Phizacklea, A. and Walter, S. (2002) 'Opportunities to work at home in the context of work-life balance', Human Resource Management Journal, Vol. 12, No. 1, pp.5476.

[7] Gupta, B. and Tyagi, A. (2009) 'Employees' perception of workplace stressors and their attitude towards work and organisation: a study of Indian managers', International Journal of Indian Culture and Business Management, Vol. 2, No. 6, pp.686-706.

[8] Haar, J.M., Russo, M., Suñe, A. and Ollier-Malaterre, A. (2014) 'Outcomes of work-life balance on job satisfaction, life satisfaction and mental health: a study across seven cultures', Journal of Vocational Behavior, Vol. 85, No. 3, pp.361-373.

[9] Hassan, Z. (2010) 'Work-family conflict in east vs. western countries', Cross Cultural Management: An International Journal, Vol. 17, No. 1, pp.30-49

[10] Heckman, N., Bryson, R. and Bryson, J. (1977) 'Problems of professional couples: a content analysis', Journal of Marriage and the Family, Vol. 39, No. 2, pp.323-330.

[11] Jayanthi, B. and Vanniarajan, T. (2012) 'Work-life imbalance among executives: a gender focus', Global Management Review, Vol. 6, No. 2, pp.24-35.

[12] Kalliath, P., Kalliath, T. and Chan, C. (2014) 'Work-family conflict and family-work conflict as predictors of psychological strain: does social support matter?', British Journal of Social Work.

[13] Komarraju, M. (1997) 'The work-family interface in India', in Parasuraman, S. and Greenhaus, J.H. (Eds.): Integrating Work and Family, Challenges for a Changing World, pp.104-114, Quorum Books, Westport, CT.study. British Journal of Social Psychology,34:87-106.

[14] Mishra, R. (1977). Working women: A frame of reference. Indian Journal of Social Research, $18(2 \& 3)$.

[15] Noor, N.M. (1995). Work and family roles in relation to women's well-being: A longitudinal study. British Journal of Social Psychology,34:87-106.

[16] Ramaiha, R.K.L. (1969). Problems of Indian working women'. In Development of Women's education, PP. 201-210

[17] Rubinstein, J.S., Meyer, D.E. and Evans, J.E. (2001) 'Executive control of cognitive processes in task switching, Journal of Experimental Psychology: Human Perception and Performance, Vol. 27, No. 4, pp.763-797.

[18] Sekaran, U. (1992) 'Middle-class dual-earner families and their support systems in urban India', inLewis, S., Izraeli, D.N. and Hootsmans, H. (Eds.): Dual-Earner Families, International Perspectives, pp.46-61, Sage, Newbury Park, CA.

[19] Skinner, D. (1980) 'Dual-career family stress and coping: a literature review', Family Relations, Vol. 29, No. 4, pp.473-481.

[20] Walston, Sandra Ford. (2002). "Women Integrating Workday Courage." Women in Business, Vol. 54, 2: 28-29.

[21] Whitehouse, G., A Hosking \& M. Baird (2008) "Returning Too Soon? Australian Mothers' Satisfactions with Maternity Leave Duration", Asia Pacific Journal of Human Resources, 46(3):288-302.

*Corresponding author.

E-mail address: jhilamrudrade@gmail.com 